already overloaded with information, to make the effort more than worthwhile. Indeed, it is said that there are enough photographs of the Moon and Mars supplied by the United States to the group at University College, London, to provide a lifetime of geological mapping. What Dr Fielder would like to see is a school with a complement of experts in solar system astronomy, planetary meteorology, geology, geomorphology and geophysics. It would be a teaching as well as a research institute. There would be outside consultants to answer specialized questions, and the school would serve to integrate the work of outside groups doing analysis of planetary samples. The bulk of the analysis of the Apollo 11 samples, for example, is by scientists who have had little contact with lunar studies. Dr Fielder seems to have approached the Science Research Council essentially for moral support, the setting up of a school of studies being more a matter for the
University Grants Committee. But there is no doubt that the time is ripe for a better organization of the planetary sciences in Britain. The problem is to find a sponsor. The school need not be expensive as scientific projects go. It ought to be at a university where there are already specialized departments and ready-made teaching facilities, and Dr Fielder estimates that space equivalent to about twenty moderately sized offices is what would be needed. The present location of Dr Fielder's group at the University of London Observatory at Mill Hill is too hemmed in to contemplate expansion, and too specialized to be the basis of what is envisaged. It is also a fact that the generous support which radio and optical astronomy alreadyreceive in Britain will make it difficult to find funds. One possibility is to seek money from an independent source such as the foundations. All the same, a planetary science institute in Britain is long overdue.

\title{
Harvard's Self-improvement
}

$\mathbf{I}_{\mathrm{T}}$ is difficult to see much reform of substance in Harvard University's new Committee on Governance. The intention behind the establishment of the committee, drawn from all the groups which comprise the university, is to produce a design for a new structure for governing Harvard. Yet the committee is the brainchild only of Harvard's small and powerful Board of Overseers. Its composition has been laid down by Harvard's president, Mr N. Pusey. It will consist of representatives of each of Harvard's nine faculties; the largest of these will send five delegates-two from the teaching staff and three students. There will be one Harvard undergraduate, one Radcliffe undergraduate and one postgraduate student. The other faculties will each send two teachers and one student. Sitting with them as they seek consensus will be a representative of the alumni, a trustee of Radcliffe, a Fellow (a lesser grandee of university government) and not one but two overseers (there are only five altogether).

The overseers found that the students' faith in the university had been shaken by the frequent absence of senior professors and the narrow, abstract and technical manner in which the teachers express their intellectual concerns. They also found that the rapid expansion of the university had created such an enormous burden of administration that the president alone could not cope with it, and needed a bigger and stronger administrative structure to help him. (This is a polite way to criticize Mr Pusey, although the overseers did

\section{Educational TV for India}

SpaCE officials tend to be carried away when they describe how money poured into what are called applications satellites is going to produce a better not go so far as the president of Yale, Mr Kingman Brewster, the other day, and suggest that university presidents, like football coaches, be given contracts with limited tenure.) And while some reform of Harvard's central governing institutions may be necessary. the overseers conclude that nothing will quickly restore the "high sense of mutual trust and confidence that formerly prevailed at Harvard". What must happenand no committee can bring it about-is that teachers must re-dedicate themselves to their primary taskteaching, and students to theirs-learning.

Yet how far should Harvard go to change itself in response to a student unrest which, the report admits, is-or was-world-wide? Some of its programmes already seem to be the very pinnacle of enlightenment. The programme for the freshman, for example, brings together first-rate teachers with small groups of seventeen and eighteen year olds. For several months, they dig into a problem of particular personal interest to the teacher. There are no examinations, no grades, but a great deal of research and discussion. Students entering Harvard and Radcliffe can choose to apply for one of forty-six seminars in topics ranging from the deformation of materials to the archaeology of the North American Indians. The programme was designed several years ago to intensify the intellectual experience of the first year. It all seems a far cry from what is supposed to incite students to riot-the hangarsized lecture hall with a tiny figure droning lecture notes into a microphone.

world for everyone; and they mean everyone, not just the inhabitants of technologicallr advanced countries. But these ornate words hide a host of doubts 
about how useful satellites like these will prove to be. To the most pessimistic, glowing praise of applications satellites is offensive because it is regarded as a sop to the have-nots who enviously watch billions of dollars going into space programmes. At times, the discussions can be heated. NASA has had its knuckles sharply rapped by a subcommittee of the House Committee on Science and Astronautics for not being more enthusiastic about earth resources satellites (see Nature 221, 611; 1969).

But it is important that two classes of applications satellites-weather satellites and communications satellites-are not tarred with the same brush. It was recently announced that the United States will cooperate with India in setting up a satellite system for bringing educational TV into 5,000 Indian villages. The plan sounds a close approximation to one of the recommendations of a recent and comparatively sober appraisal of applications satellites by the US National Research Council (Useful Applications of EarthOriented Satellites, Report of the Central Review Committee, National Academy of Sciences, \$2). The report says that two classes of broadcasting satellites "seem so easy technically, so reasonable economically and so potentially desirable" that a quick start should be made on them. One is educational TV for developing countries. (The other is a similar distribution system for use by private and public industry in the United States.)

Under the agreement with India, the sixth of NASA's series of Applications Technology Satellites will receive TV programmes transmitted from a ground station at Ahmedabad and relay them to small village receivers. The programmes will be under Indian control and are expected to be directed at family planning, education in agriculture and to make a much-needed contribution to Indian unity. Direct broadcasting to village receivers is made possible by an increase in the power which can be provided on Geostationary satellites, and by a highly directional aerial, which in turn means that the receivers on the ground can be modest and inexpensive. The satellite will not be launched until the middle of 1972, and it will be some time after that when the efficacy of the system is known. Limited experiments with conventional TV broadcasting to villages around New Delhi suggest that there may be a bright future ahead. Everybody will be hoping for just that.

\section{INNOVATION \\ Good Year for NRDC}

Althоugh the National Research Development Corporation is still some way off the commercial success it promises, its report for its twentieth year, 1968-69, shows that last year's upward trend seems to have been maintained or even bettered. Obviously the doubling of the corporation's capital to $£ 50$ million last year has helped. Happily, the NRDC reports that, last year, income was a record $£ 2.5$ million com- pared with $£ 1 \cdot 3$ million in $1967-68$. Royalty receipts from licence agreements make up $£ 1.9$ million of the total (compared with $£ 1 \cdot 2$ million), of which roughly $£ 1.5$ million was in foreign currency. But outgoings are also up- $£ 5.2$ million compared with $£ 3.3$ million, so that the excess of outgoings over income has increased by $£ 700,000$. The excess is financed by borrowings from the Ministry of Technology, the corporation's master. For the first time, however, the corporation has a surplus on revenue account, $£ 48,000$ compared with last year's deficit of $£ 601,000$, and expects to continue on this basis for the next two or three years.

NRDC considers that projects based on a range of variants to the hovercraft principle, on carbon fibres and on microelectronics are of particular national importance. It is also counting on underwater technology and meteorological instruments to play an important part in the future. For the time being, however, the corporation's chief sources of income are still pharmaceuticals, with cephalosporin leading the field followed by tri-iodothyronine. Selective weedkillers have turned out to be good earners.

The list of projects under the corporation's wing last year reflects the usual diversions. They include a pea-pod harvester invented by Mr E. N. Vellacott, a farmer; a technique for the fluid bed drying of tea; antilymphocyte serum; and a trenchless pipelayer. A project to identify the active components of raspberry leaves, used in herbal medicine for many years, has been wound up because of technical difficulties, and so has an attempt to market a vaccine for the common cold.

Twenty-four per cent of NRDC projects are in the hands of firms with less than twenty-five employees, and twenty-four per cent are with firms of more than five hundred employees. But, as might be expected, the small firms receive only two per cent of the expenditure compared with the seventy-one per cent spent by the larger firms.

\section{SCIENCE POLICY}

\section{Dainton in Charge}

DR F. S. Dainton, one of the founder members of the Council for Scientific Policy and well known for his report on the swing from the physical sciences to arts and the social sciences, is to become chairman of the council when Sir Harrie Massey retires at the end of the year. At present, Dr Dainton is Vice-Chancellor of the University of Nottingham. Dr Dainton is known to be a man of great determination, and has done noble work in making Nottingham the centre of the project for adapting automatic sources of chemical information, largely American in origin, to British needs. It will be interesting to see whether his appointment at the Science Research Council will mean the resurrection of interest in his own sub-committee's recommendations on the redrawing of the boundaries between British schools and universities, largely neglected since they first appeared more than a year ago. The council's efforts at present are centred on four working groups. A group under Dr R. D. Keynes is looking at ways of matching the supply to the demand for qualified biologists. Another under Sir Harrie Massey is examining various possible ways of providing 